\title{
Water on Mars: Do submarine cyclic steps exist on the red planet?
}

\author{
Svetlana Kostic ${ }^{1^{*}}$ and Isaac B. Smith ${ }^{2}$
}

\begin{abstract}
Submarine cyclic steps have a significant impact on the evolution of the ocean floor on Earth. These upper-flow regime bedforms should be even more common in Martian reduced-gravity environments. We postulate that, if early Mars had an ocean, cyclic steps would have formed on Martian deltas spreading along the putative ancient shorelines in the northern plains. The main challenge to identifying submarine cyclic steps on Mars is geologic activity, in particular impacts, volcanism, and aeolian erosion, which have erased or modify much of the geomorphic evidence. Even though many Martian deltaic deposits do not bear much resemblance to the original depositional surfaces, we hypothesize that cementation and consolidation of marine sediments had facilitated the preservation of at least some Martian cyclic steps on deltaic deposits. We combine data from several orbital missions at Mars with a literature review and numerical analysis to inspect bedforms near the foreset-bottomset transition of 17 documented deltaic deposits. The most promising piece of evidence for Martian submarine cyclic steps is a linear series of rhythmic long-wavelength bedforms within a channel incised into the upper delta front of the Aeolis Mensae Delta. These bedforms are remarkably similar to their counterparts observed in channels on deltas and deep-water fans on Earth. Moreover, we speculate that two fields of cyclic steps, likely emanating from a crater upstream of the Aeolis Mensae Delta, are a potential example of contemporary cyclic steps and attest to the sporadic presence of flowing water on present-day Mars.
\end{abstract}

Keywords: Water on Mars, Martian ocean, Delta, Martian submarine cyclic steps, Foreset deposit, Foreset-bottomset transition, Aeolian bedforms, Reduced gravity, Inverted channel, Consolidation of submarine sediments

\section{Introduction}

\section{Ancient ocean on Mars}

The paradigm that early Mars could have supported a complex hydrological system and an ancient ocean located in the low-lying northern plains (Fig. 1) is one of the most challenged concepts in Mars research (Baker et al. 1991; Parker et al. 1989, 1993; Malin and Edgett 1999; Head et al. 1999; Ivanov and Head 2001, Fairen et al., 2003; Carr and Head 2003; Ghatan and Zimbelman 2006; McEwen et al. 2007). Yet, the evidence for the northern hemispheric Martian ocean is mounting steadily. Among most compelling is the recent work of Citron et al. (2018) and Villanueva et al. (2015). The putative shorelines in the northern plains (e.g., Parker et al. 1989; Carr and Head 2003) fail to follow an equipotential surface,

\footnotetext{
* Correspondence: skostic@sdsu.edu

${ }^{1}$ Computational Science Research Center, San Diego State University, San

Diego, CA, USA

Full list of author information is available at the end of the article
}

which has been commonly used to challenge the existence of an early ocean (e.g., Malin and Edgett 1999). Citron et al. (2018) confirmed that variations in shoreline topography could be explained by the emplacement of Tharsis (Perron et al. 2007), a volcanic province that dominates the gravity and topography of Mars. However, their work demonstrates that the shorelines must have formed before and during the emplacement of Tharsis. The results indicate a close relationship between the evolution of the Martian ocean and the initiation and decline of Tharsis volcanism. More importantly, they imply that the Martian ocean formed concurrent with the valley networks (Bouley et al. 2016), which is significantly earlier than previously thought and have broad implications for the geology, hydrological cycle, and climate of early Mars. Villanueva et al. (2015) used observations of the present-day deuterium (hydrogen with an extra neutron) to hydrogen ration $(\mathrm{D} / \mathrm{H})$ to model how much water has escaped into space over Martian history. They suggest that early Mars (4.5 


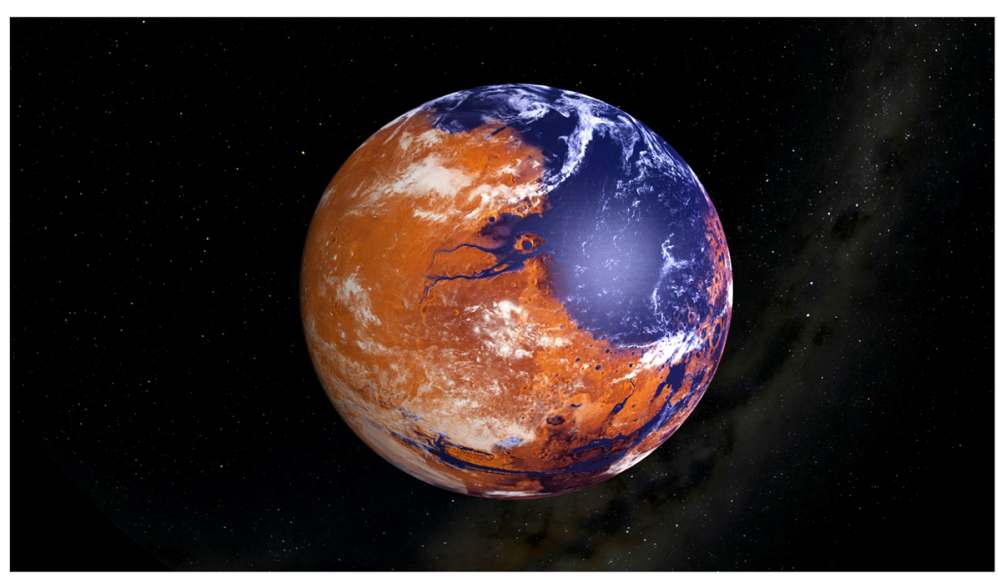

Fig. 1 Rendition of the ancient ocean occupying nearly half of Martian northern hemisphere (NASA's Goddard Space Flight Center public domain image)

billion years ago) had a global equivalent water layer of at least $137 \mathrm{~m}$, enough to fill the many basins on the planet. Evidence from the surface of Mars today implies that this water at least temporarily pooled to form an ocean in the low-lying northern plains (Fig. 1). The primordial ocean could have held more water than Earth's Arctic Ocean and covered $19 \%$ of the planet's surface (in contrast to the Atlantic Ocean, which occupies $17 \%$ of the Earth's surface).

Other earlier observations and important evidence for the ocean encompass the interpretation of ancient shorelines from Viking Orbiter images (Parker et al. 1993), the topography of deformed shorelines (Perron et al. 2007), global distribution of Martian deltas and valleys within and along the margins of the northern lowlands (Di Achille and Hynek 2010), a branching network of inverted channel and channel-lobe deposits at Aeolis Dorsa (DiBiase et al. 2013), and tsunami deposits with runout lobes and backwash erosion (Rodriguez et al. 2016; Costard et al. 2017). For years, the controversial paleo-shoreline interpretation (Parker et al. 1989, 1993) has driven research in a very specific direction of documenting terrestrial analogs for the deposits located on the northern plains, where the hypothetical ocean existed. Some of the most convincing evidence includes a resemblance between teardrop-shaped islands in Martian outflow channels and erosional shadow remnants documented in deep-water environments on Earth (Moscardelli and Wood 2011), terrestrial submarine analogs for streamlined forms on Mars (Burr 2011), similarities between large-scale polygonal terrains on Mars and deep-water polygonal fault systems on Earth (Cooke et al. 2011; Allen et al. 2013; Moscardelli et al. 2012), comparisons between high-albedo mounds in Acidalia Planitia and terrestrial submarine mud volcanoes (Allen et al. 2013; Oehler and Allen 2012), and resemblance between boulder-size rocks contained within the Vastitas Borealis
Formation on the northern plains of Mars and blocks and boulders that have been documented in deep-water terrestrial environments and reported in outcrop (Moscardelli 2014).

The work presented herein provides an additional line of evidence for the northern hemispheric ocean by recognizing a new class of bedforms on Mars called submarine cyclic steps. Submarine cyclic steps (Fig. 2) are rhythmic, upstream-migrating bedforms bounded by internal hydraulic jumps in overriding turbidity currents (Kostic and Parker 2006). They signify one manifestation of fundamental morphodynamic instability of Froudesupercritical flow over an erodible bed (Kostic 2011). We use submarine analogs on Earth and compare their morphology and geometry to properties of channelized features on Martian deltas in order to establish that submarine cyclic steps exist on Mars. We postulate that these bedforms are created by the same processes (i.e., sediment gravity flows) on our planet and on Mars. Channelized cyclic steps are particularly instrumental in the analysis presented herein as they are net-erosional features, which cannot be mistaken for aeolian net-depositional bedforms.

\section{Research objective, hypotheses, and challenges}

The focused objective of this research is to evaluate whether submarine cyclic steps are present on 17 deltaic deposits documented by Di Achille and Hynek (2010), which spread along the putative shorelines of a primordial northern ocean (Fig. 3). The presence of a slope break is a necessary, but not sufficient, condition for the spontaneous evolution of an erodible plane bed into cyclic steps on deep-sea fan-deltas on Earth (Kostic 2011). The foreset-bottomset transition (Fig. 4) associated with a transition from a steep delta front or foreset deposit to a mildly sloping bottomset deposit constitutes such a slope break. Thus, we hypothesize that the foreset-bottomset 


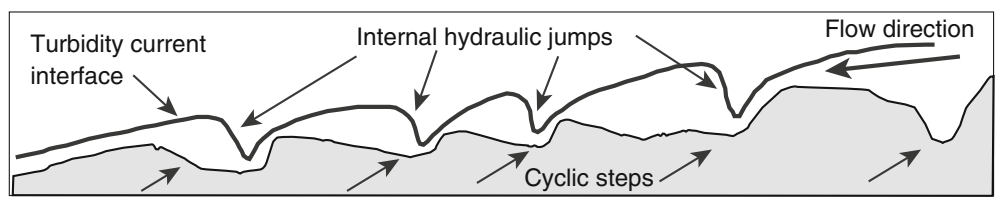

Fig. 2 Schematics of submarine cyclic steps bounded by internal hydraulic jumps (modified from Fildani et al. 2006)

transition on Martian deltas could have triggered the formation of submarine cyclic steps analogous to their terrestrial counterparts (e.g., Normandeau et al. 2016) in both process and form.

The main challenge of this research is that the current Mars topography provides an imperfect record of its depositional/erosional history because of resurfacing caused by impacts, volcanism, and mass wasting, as well as ongoing aeolian and likely occasion fluvial modification. Widespread aeolian surface modification is a particularly important factor in ongoing surface processes (Irwin III and Zimbelman 2012). Assuming e.g. a late Hesperian ocean was present (Fairen et al. 2003), it is questionable whether the morphologic signature of cyclic steps $\left(\mathrm{O}\left(1-10^{2} \mathrm{~m}\right)\right.$ height, $\mathrm{O}\left(10-10^{3} \mathrm{~m}\right)$ wavelength) would be preserved. We postulate that Martian northern deltas are likely to host remnants of ancient cyclic steps, because marine bed sediments tend to develop strength over time through consolidation, and thus resist erosion. Furthermore, we assume that remnants of cyclic steps are more likely to be preserved on deltas displaying inverted channels due to cementation (DiBiase et al. 2013) as these deltas are more resistant to weathering and erosion.

\section{Submarine cyclic steps as new analog for Martian streamlined forms emplaced by turbidity currents}

Cyclic steps emplaced by turbidity currents are common features on the ocean floor of Earth (e.g., Kostic 2011). They were first discovered in numerical experiments on internal hydraulic jumps (Kostic and Parker 2006). Since then, they have swiftly gained recognition as important building blocks of deep-water depositional systems in both unconfined and confined submarine environments (e.g., Fildani et al. 2006, 2013; Kostic 2011, 2014; Cartigny et al. 2011; Covault et al. 2014, 2017; Hamilton et al. 2015; Postma et al. 2016).

Submarine cyclic steps should be more prevalent on Mars than on our planet. This becomes apparent from the densimetric Froude number $F r_{d}$ for turbidity currents that can be written as:

$$
F r_{d}=U / \sqrt{R C g H}
$$

where $H$ is an appropriate measure of turbidity current thickness, $U$ is the layer-averaged flow velocity, $g$ is the acceleration of gravity, $C$ is the layer-averaged volume concentration of suspended sediment carried by the turbidity current $(C<<1)$, and $R$ is the submerged specific gravity of the sediment (which is close to 1.65 for most natural sediments). For the same values of flow velocity $U$, concentration of suspended sediment $C$, and turbidity current thickness $H$, turbidity currents on Mars should be intrinsically more biased toward supercritical flows than their analogs on Earth due to the significantly lower gravitational acceleration $\left(g=3.7 \mathrm{~m} / \mathrm{s}^{2}\right.$, which is a little over $1 / 3$ of the acceleration of gravity on Earth). By extension, it should be more likely for slope breaks on Mars (such as e.g. the foreset-bottomset transition) to

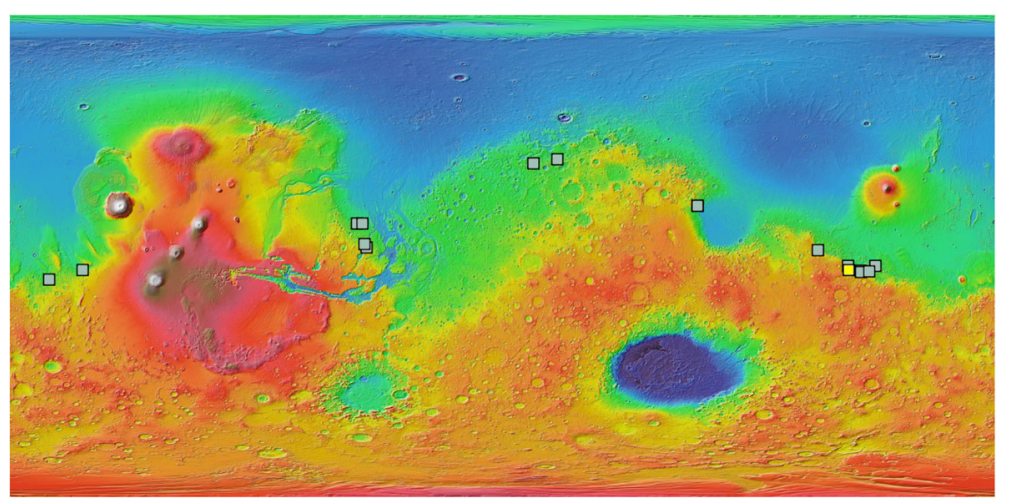

Fig. 3 MOLA topography of the low-laying northern plains of Mars with white squares showing remnants of 17 deltaic deposits identified by Di Achille and Hynek (2010). The yellow square indicates the location of Aeolis Mensae Delta 


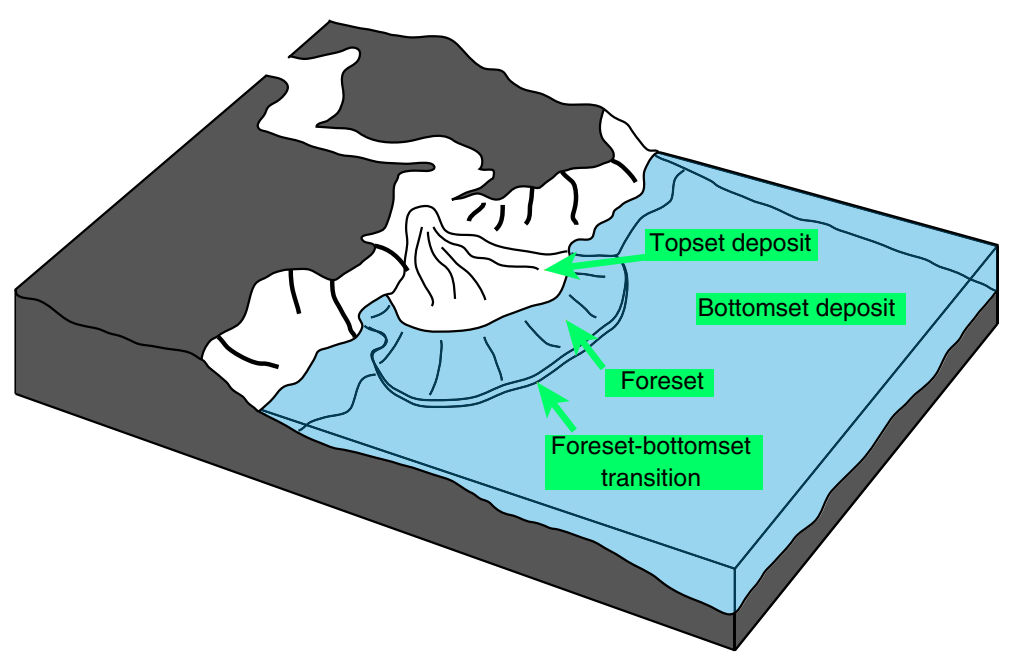

Fig. 4 Structure of a typical deltaic deposit on Mars (modified from Di Achille and Hynek 2010). Schematic diagram illustrates a topset (also called delta plain), foreset (also called delta front), and bottomset deposit (also called delta base), as well as the foreset-bottomset transition. Under the right conditions, the foreset-bottomset transition generates submarine cyclic steps

trigger internal hydraulic jumps and associated cyclic steps under the right conditions.

\section{Formative conditions for Martian submarine cyclic steps}

The dimensionless parameters that control the formation of submarine cyclic steps are summarized in Kostic (2011). Two of them, i.e., the dimensionless fall velocity $v_{s} / U_{o}$ and the drop in bed Shields number $\Delta \tau^{*}$ across the jump, are particularly important for the analysis at hand. The dimensionless fall velocity $v_{s} / U_{o}$ defines the ratio of the sediment fall velocity $v_{s}$ to layer-averaged inflow velocity $U_{o}$. This parameter can be useful in estimating the cutoff size of sediment that causes turbidity currents to undergo internal hydraulic jumps (Kostic 2011). Supercritical turbidity currents driven by sediment fine enough to satisfy the approximate condition

$$
\frac{v_{s}}{U_{o}}<3 \times 10^{-3}
$$

regularly display an internal hydraulic jump induced by the slope break, whereas the coarse-grained turbidity currents with the ratio

$$
\frac{v_{s}}{U_{o}}>5 \times 10^{-3}
$$

do not undergo a transition to subcritical flow due to a rapid rate of sediment deposition on the bed (Kostic and Parker 2006; Kostic 2011). When an internal hydraulic jump occurs in response to a slope break, it is not always strong enough to leave a clear depositional signal in associated depositional record. A drop in the bed Shields number $\Delta \tau^{*}$ quantifies the corresponding drop in mobility of bed sediment across the jump, such that:

$$
\Delta \tau^{*}=\left(\frac{\Delta u_{*}}{\mathrm{v}_{s}} R_{f}\right)^{2}
$$

where $\Delta u_{*}$ denotes the drop in shear velocity across the jump and $R_{f}$ is a dimensionless particle fall velocity, given by:

$$
R_{f}=v_{s} / \sqrt{R g D}
$$

with $D$ being the mean grain size of sediment. The drop in bed Shields number across the jump needs to satisfy the following crude criterion to yield a detectable depositional signal (Kostic and Parker 2006; Kostic 2011):

$$
\Delta \tau^{*}>3
$$

The analysis in Table 1 was carried out for median grain size taking values of $20,50,80,100,150$, and $200 \mu \mathrm{m}$. The results imply that the formation of cyclic steps on Mars can be triggered by flows that are about $60 \%$ slower than their counterparts on Earth (i.e., the ratio $k$ in Table 1). For example, a turbidity current driven by $50-\mu \mathrm{m}$ sediment on Mars should have the inflow velocity of the order of $30 \mathrm{~cm} / \mathrm{s}$ or higher (in contrast to over $70 \mathrm{~cm} / \mathrm{s}$ on Earth) to trigger submarine cyclic steps. For a $100-\mu \mathrm{m}$ turbidity current, the inflow velocity higher than $1.0 \mathrm{~m} / \mathrm{s}$ (in contrast to $2.5 \mathrm{~m} / \mathrm{s}$ on Earth) is necessary for steps to emerge.

Other results from Table 1 that should interest the planetary science community can be summarized as following: If the incoming flow velocity is less than $17 \mathrm{~cm} / \mathrm{s}$ for a $50-\mu \mathrm{m}$ current and $62 \mathrm{~cm} / \mathrm{s}$ for a $100-\mu \mathrm{m}$ current, the turbidity current after a slope break remains supercritical and cyclic steps never form. For higher underflow velocity of the order of 3-4 m/s the cutoff size for 
Table 1 Calculated formative conditions for submarine cyclic steps on Earth and Mars

\begin{tabular}{|c|c|c|c|c|c|c|c|}
\hline & Ds $(\mu \mathrm{m})$ & 20 & 50 & 80 & 100 & 150 & 200 \\
\hline \multicolumn{8}{|l|}{ On Earth } \\
\hline & $v_{s}(\mathrm{~cm} / \mathrm{s})$ & 0.04 & 0.22 & 0.51 & 0.74 & 1.43 & 2.20 \\
\hline Always steps & $U_{0}(\mathrm{~cm} / \mathrm{s})^{a}>$ & 11.8 & 72.6 & 169.5 & 247.9 & 476.5 & 734.6 \\
\hline \multirow[t]{3}{*}{ No steps } & $U_{0}(\mathrm{~cm} / \mathrm{s})^{\mathrm{b}}<$ & 7.1 & 43.5 & 101.7 & 148.7 & 285.9 & 440.8 \\
\hline & $R_{f}$ & 0.020 & 0.077 & 0.141 & 0.185 & 0.290 & 0.388 \\
\hline & $\Delta u^{*}(\mathrm{~cm} / \mathrm{s})^{c}>$ & 3.1 & 4.9 & 6.2 & 7.0 & 8.5 & 9.8 \\
\hline \multicolumn{8}{|l|}{ On Mars } \\
\hline & $v_{s}(\mathrm{~cm} / \mathrm{s})$ & 0.01 & 0.08 & 0.21 & 0.31 & 0.62 & 0.98 \\
\hline Always steps & $U_{0}(\mathrm{~cm} / \mathrm{s})^{\mathrm{a}}>$ & 4.3 & 28.2 & 68.6 & 102.5 & 204.9 & 325.1 \\
\hline \multirow[t]{3}{*}{ No steps } & $U_{0}(\mathrm{~cm} / \mathrm{s})^{b}<$ & 2.6 & 16.9 & 41.2 & 61.5 & 122.9 & 195.1 \\
\hline & $R_{f}$ & 0.012 & 0.048 & 0.093 & 0.124 & 0.203 & 0.279 \\
\hline & $\Delta u^{*}(\mathrm{~cm} / \mathrm{s})^{c}>$ & 1.9 & 3.0 & 3.8 & 4.3 & 5.2 & 6.1 \\
\hline \multicolumn{8}{|l|}{ Comparison } \\
\hline \multirow[t]{2}{*}{ Always steps } & $k^{d}$ & 0.64 & 0.61 & 0.60 & 0.59 & 0.57 & 0.56 \\
\hline & $m^{e}$ & 0.39 & 0.39 & 0.39 & 0.39 & 0.39 & 0.39 \\
\hline
\end{tabular}

Note: ${ }^{\mathrm{a} E q .}$ (2), ${ }^{\mathrm{b}}$ Eq. (3), ${ }^{\mathrm{C}}$ Eq. (6), ${ }^{\mathrm{d}}\left(U_{0}\right.$ Earth $\left.-U_{0}{ }^{\text {Mars }}\right) / U_{0}{ }^{\text {Earth }},{ }^{\mathrm{e}}\left(\Delta u^{* \text { Earth }}-\Delta u^{* \text { Mars }}\right) / \Delta u^{* \text { Earth }}$

submarine cyclic steps is roughly between 100 and $150 \mu \mathrm{m}$ on Earth, and between 200 and $300 \mu \mathrm{m}$ on Mars. The required drop in shear velocity across the jump that yields detectable cyclic steps on Mars is $40 \%$ lower than on Earth (i.e., the ratio $m$ in Table 1).

\section{Examples of potential terrestrial analogs in channels}

The focus here is on cyclic steps in channels (Fildani et al. 2006; Smith et al. 2007; Lamb et al. 2008; Maier et al. 2012; Fildani et al. 2013; Covault et al. 2014; Tubau et al. 2015) and their role in channel initiation and maintenance. In particular, we review cyclic steps in the Monterey East Channel (Fildani et al. 2006) and San Mateo Channel (Covault et al. 2014) in California as potential terrestrial analogs for channelized cyclic steps on Martian deltas. The Monterey East system in central California is a unique deep-water environment to study cyclic steps as a means of channel initiation on modern submarine fans. Fildani et al. (2006) combined high-resolution acoustic data with numerical modeling to investigate the Monterey East Channel at the Monterey Fan. This fan segment is characterized by a linear train of large crescent-shaped scours incised into large-scale sediment waves at the outer levee of the Monterey Channel at the Shepard Meander (Fig. 5a). The scours in the channel range from 3 to $5 \mathrm{~km}$ in width, 3 to $6 \mathrm{~km}$ in length, and 80 to $200 \mathrm{~m}$ in depth. Fildani et al. (2006) offer evidence that these features constitute net-erosional cyclic steps carved by supercritical turbidity currents stripped from the main flow in the Monterey Channel moving through the meander. The formative supercritical flows were postulated to have focused through a breach in the levee, likely triggered by slumping of the steep meander wall. More importantly, net-erosional cyclic steps were recognized for the first time as a means of the early stage of an eventual avulsion from the present-day Monterey Channel and initiation of a new channel named the Monterey East Channel.

The San Mateo Channel located on a tectonically active slope offshore of southern California is another valuable deep-water environment to study channel initiation, filling, and maintenance by way of generation of cyclic steps. Covault et al. (2014) combined numerical experiments with interpretations of sea-floor and shallow subsurface stratigraphic imagery to examine a series of flute-shaped bedforms along the preset-day channel thalweg (Fig. 5b). These features, ranging in wavelength from 0.3 to $1.1 \mathrm{~km}$ and in height from 20 to $50 \mathrm{~m}$, were identified as net-depositional cyclic steps emplaced by turbidity currents and credited with the channel maintenance. Moreover, numerical simulations suggested that an incipient, proto-San Mateo Channel was originally initiated by way of a series of net-erosional cyclic steps, which nucleated out of sea-floor perturbations across the tectonically active lower slope.

The Gravel River emptying into fjord-Lake Walker in Canada is selected as an additional delta analog for channelized cyclic steps on Martian deltas. The mean foreset slope of the Gravel River Delta is $4^{\circ}$, although the upper slope is significantly steeper, reaching $12^{\circ}$. Normandeau et al. (2016) reported noticeable bedforms covering an approximate area of $633,500 \mathrm{~m}^{2}$ of the delta 


\section{a}

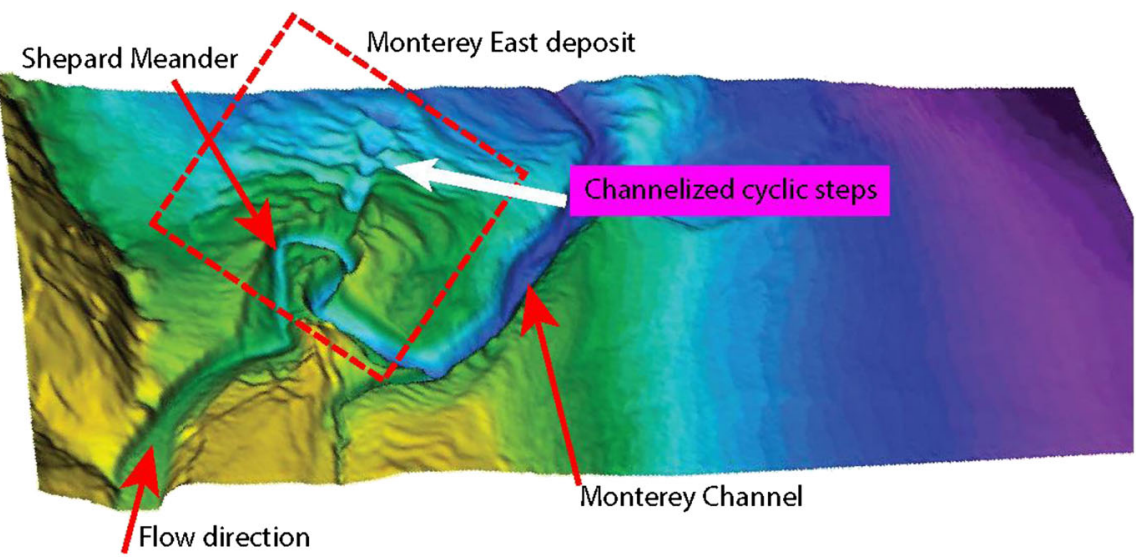

b

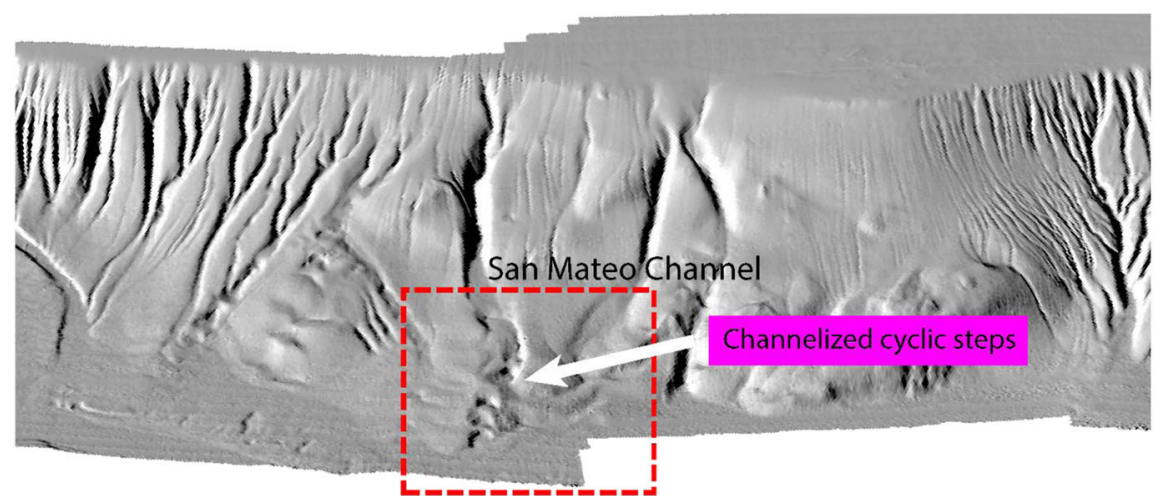

Fig. 5 Cyclic steps in submarine channels on Earth as analogs for bedforms on Martian deltas. a Large-scale net-depositional cyclic steps on the outer levee of the Shepard Meander dissected by a linear train of net-erosional cyclic steps in the Monterey East Channel, California, USA (image courtesy A. Fildani; high vertical exaggeration is to enhance bedforms); b A series of cyclic steps along the thalweg of the San Mateo Channel, California, USA (modified from Covault et al. 2014)

front (Fig. 6). These features have a mean wavelength of $35 \mathrm{~m}$ and a mean height of $2.2 \mathrm{~m}$. They are mostly channelized between depths of 25 and $100 \mathrm{~m}$, but also occur on the open delta plain. Normandeau et al. (2016) used the shape of the bedforms and the relationships between their morphological properties to demonstrate that these features were likely cyclic steps emplaced by supercritical turbidity currents. The underflows on the Gravel River Delta were attributed to hyperpycnal flows, even though there was also some evidence of delta-front slope failures.

All three selected terrestrial analogs are useful in their own way for identification and classification of channelized cyclic steps on Martian deltas. The Monterey East Channel analog establishes cyclic steps as a means of initiation of a new channel. The San Mateo Channel analog distinguishes between net-erosional cyclic steps as a means of channel initiation and net-depositional cyclic steps as a means of channel maintenance. The Gravel River Delta, even though not in a marine setting, illustrates well the effect of the foreset-bottomset transition on the formation of channelized cyclic steps on the foreset deposit.

\section{Can cyclic steps form on Mars? Aeolian cyclic steps}

Cyclic steps were already discovered on Mars in an unexpected environment: the polar ice caps (Smith et al. 2013). They are attributed to atmospheric processes, i.e., katabatic winds and asymmetric ice accumulation. Katabatic winds have been studied extensively on Earth (Ball 1956; Pettré and André 1991) and have analogous properties to turbidity currents in submarine environments. They experience disruptive katabatic jumps that behave similarly to internal hydraulic jumps in turbidity currents. At the Martian polar caps, the cold air on top of the polar plateau densifies and begins to flow downhill, beneath the ambient air, as seasonal katabatic winds reaching speeds upwards of $20 \mathrm{~m} / \mathrm{s}$ (Smith et al. 2013). The winds are disturbed by katabatic jumps similar to terrestrial katabatic jumps, but with one notable difference. Air is more compressible on Mars, so the fluid at the katabatic jump decompresses, lowering the atmospheric temperature enough to create water-ice clouds instead of preserving the water vapor (Smith et al. 2013). Additionally, the winds are unimpeded by 


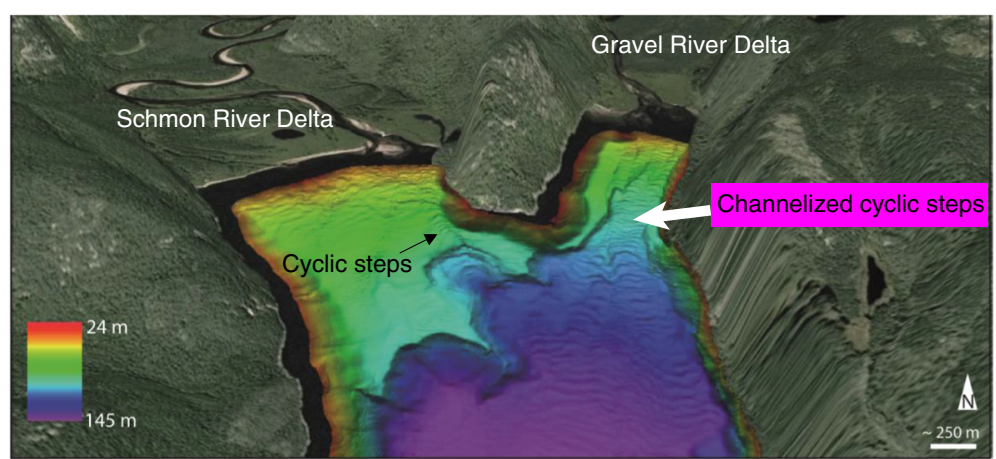

Fig. 6 Cyclic steps observed on deltas on Earth. Channelized and unconfined cyclic steps on foreset deposits of fjord-lake deltas at the Gravel River and Schmon River, Québec, Canada, (modified from Normandeau et al. 2016)

regional topography, so the southward slope drives the primary direction of the winds, and the Coriolis force steers them clockwise, setting up a recognizable spiraling pattern of polar troughs emplaced by katabatic winds.

Figure 7 illustrates curvilinear depressions called spiral troughs of the Norther Polar Layered Deposits (NPLD). These aeolian features are stratigraphy consistent with net-depositional cyclic steps and have a characteristic wavelength from 20 to $70 \mathrm{~km}$ and wave heights of the order of 400 to $1000 \mathrm{~m}$ (Smith and Holt 2010; Smith et al. 2013). They have migrated approximately $50 \mathrm{~km}$ upslope in two million years (Fig. 7b; Smith et al. 2013). The scale of aeolian cyclic steps, which is well beyond the scale of submarine cyclic steps, and their signature spiral pattern make them easily distinguishable from submarine cyclic steps.

\section{Aeolian transverse ridges}

Mars exhibits many aeolian bedforms besides polar spiral troughs. First, large dunes of black olivine- and pyroxene-rich sand are found in many dune fields across the planet. These have identical forms to dunes on Earth, namely barchanoid and parabolic shapes and longitudinal and latitudinal dunes with fingering modes. Some confined locations, i.e., within large craters, may contain star dunes hundred kilometers tall. In many locations, the dunes have been observed to migrate with the same behavior and sediment flux of terrestrial dunes a

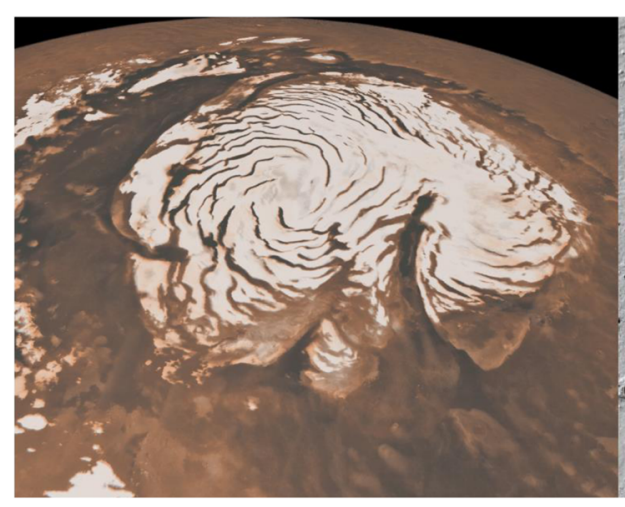

b

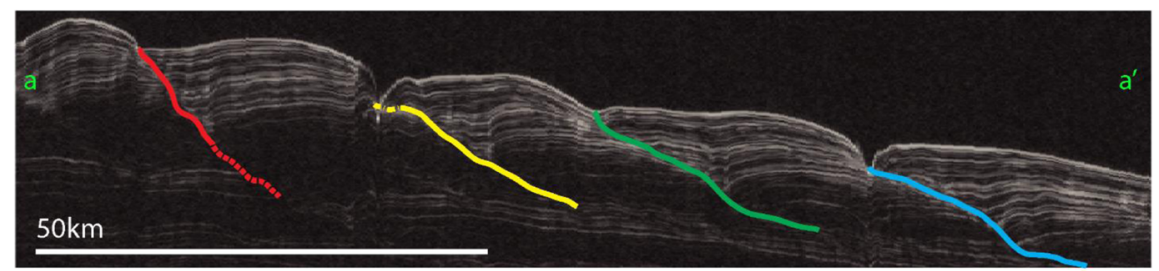

Fig. 7 Aeolian cyclic steps on the North Pole of Mars (modified from Smith et al. 2013). Shaded relief surface from MOLA elevation data demonstrates that a spiral troughs cover majority of the polar cap (left) and display a recognizable spiraling pattern due to the direction of katabatic winds working together with the Coriolis force (right). SHARAD profile a-a' shows $\mathbf{b}$ stratigraphy associated with spiral trough migration 
(Silvestro et al. 2010; Bridges et al. 2012', 2012b), except where hindered by seasonal $\mathrm{CO}_{2}$ frost at the polar caps.

Besides the sand dunes, another aeolian bedform is expressed across much of the Mars surface. These are called transverse aeolian ridges, or TARs (Balme et al. 2008; Zimbelman 2010; Fig. 8). TARs are not well understood. They are mid-way in height between dunes and ripples. Unlike the dark sand that comprises the dunes, TARs frequently consist of light-toned sand due to induration and are immobile. None have been observed to move, even over time spans greater than a decade (Zimbelman 2010). They are believed to be cemented material from a previous period in Martian history.

Both TARs and dunes are always positive relief features, frequently observed in fields among similar features (Figs. 8 and 9). They are common in low places like valley floors. These features can be sometimes confused for net-depositional cyclic steps, especially in unconfined environments. This is in part why this work focuses on channelized net-erosional cyclic steps, which are quite distinctive upper-flow regime bedforms.

\section{Methods/experimental}

In seeking cyclic steps in submarine deposits, we analyzed high resolution context imager (CTX, Malin et al. 2007) data over 17 open basin deltas recognized by $\mathrm{Di}$ Achille and Hynek (2010). CTX has approximately $6 \mathrm{~m} /$ pixel resolution and full coverage over these features. Additionally, data from the High Resolution Imaging Science Experiment (HiRISE, McEwen et al. 2007) was consulted when greater detail was necessary. HiRISE has a resolution of roughly $0.5 \mathrm{~m} /$ pixel, but lower coverage. The JMARS geospatial information system platform loads the georeferenced images automatically, and we used this tool to make the mosaics (Christensen et al. 2009). Once the data were loaded, we sought periodic structure in the visible imagery and analyzed CTX mosaics at ever site.

To measure slopes and elevation, we first used gridded data from the Mars Orbital Laser Altimeter (MOLA,
Smith et al. 2001) and then digital terrain models (DTMs) generated from stereo pairs of the High Resolution Stereo Camera (HRSC, Neukum and Jaumann 2004). From those products, we were able to extract elevations and traverse distance, and then derive slopes and bedform characteristic wavelengths.

\section{Results}

\section{Setting}

Aeolis Mensae is located close to the volcanic region of Elysium and near the boundary (i.e., hemispherical topographic dichotomy) between the heavily cratered highlands in the southern hemisphere and the flat, sparsely cratered plains that cover most of the northern hemisphere of Mars (Irwin III et al. 2004). This region of Mars is of particular geological interest as it has been shaped by a powerful combination of tectonic activity and wind activity in the transitional zone between the highlands and lowlands. Thus, the scenery of the region includes many unusual features such as tectonic grabens, mesas, and sinuous and linear ridges. Numerous tectonic grabens (or fracture zones) crossing this region are the result of the Martian crust stretching apart under tectonic activity early in Mars' history. The occasional stranded blocks called freestanding mesas rise above the surrounding terrain as remnants of the crust's expansion. They have been eroded by wind, and possibly water and ice for over millions of years, and will disappear in the distant future. Several sinuous ridges in the region exhibit strong characteristics of ancient channels that have become inverted, as illustrated in Fig. 9. This positive relief in channels is attributed to early sediment cementation (DiBiase et al. 2013), which makes channels more resistant to weathering and erosion than surrounding floodplain material. Linear ridges, also called yardangs, frequently observed on the sides of inverted channels indicate the course of the prevailing wind over a long period of time.

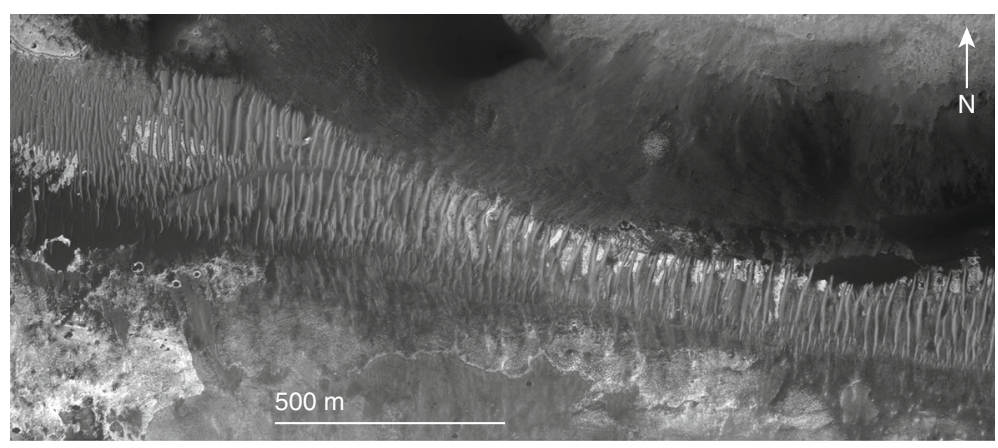

Fig. 8 Aeolian dunes in a channel on Mars 


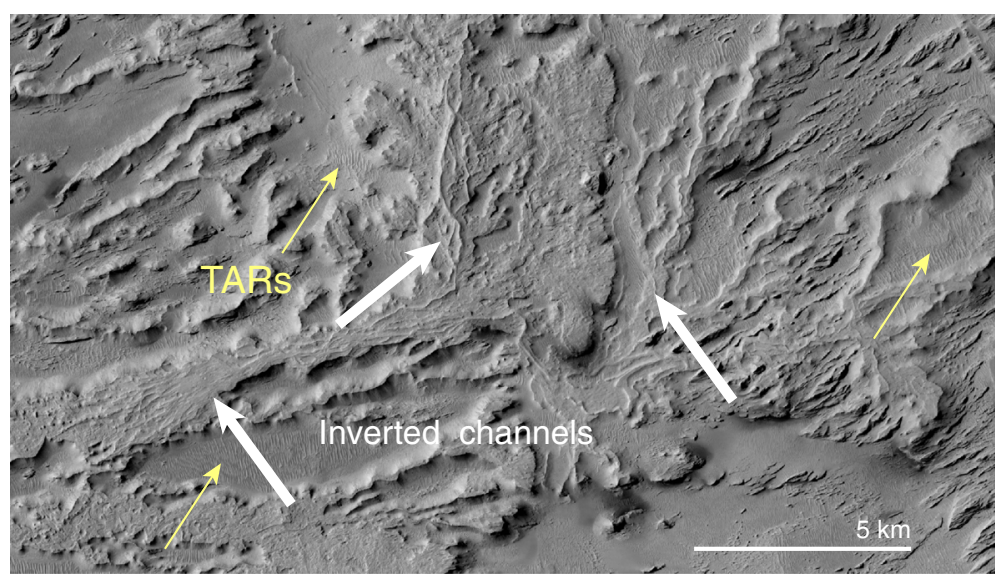

Fig. 9 Aeolis Mensae perspective, illustrating TARs and inverted channels

\section{Aeolis Mensae Delta}

We examine a deltaic deposit centered at $132.861^{\circ} \mathrm{E}$, $5.149^{\circ} \mathrm{N}$ near the rim of Robert Sharp Crater, west of Gale Crater. The Aeolis Mensae Delta resides downstream of a canyon that enters the crater from the southwest. The mouth of the canyon leading to the delta is at $-2357 \mathrm{~m}$ elevation (below mean elevation of the planet), and the topset deposit varies in elevation around $-2580 \mathrm{~m}$.

The catchment of water is from the south, where an extensive valley network drained water into the canyon that fed the delta (Fig. 10a, b). Because the setting is within a crater, the rim acted as the boundary of the basin, and the shoreline would have been on steep slopes. The delta measures nearly $20 \mathrm{~km}$ across and $11.5 \mathrm{~km}$ from mouth to foreset-bottomset transition. A massive mesa, taller than the mean elevation of the delta, blocked the delta from prograding toward the east (Fig. 10b).

The upper foreset deposit of the Aeolis Mensae Delta is steep, with a mean slope of $2^{\circ}$. It should be noted that the local slopes are greater than the mean slope due to a poor resolution of interpolated data. For example, local foreset slopes in the vicinity of field 1 and field 2 (Fig. 10b) are of the order of $3^{\circ}$ and $3-5^{\circ}$, respectively. There is a distinct break in slope between upper and lower foreset beds, with the lower delta front being quite short, i.e., spreading over a distance of about $100-110 \mathrm{~m}$.

\section{Aeolis Mensae Delta bedforms}

We found evidence of three distinctive fields of bedforms on the upper foreset deposit of the Aeolis Mensae Delta, as illustrated in Fig. 10b. The first field (field 1 in Fig. 10b, c) includes a linear train of crescent-shape scours within a channel leading from the feeder canyon, as well as broader un-channelized constructive bedforms immediately outside of this channel. Further east, there are two more fields of wave-like bedforms (field 2 and field 3 in Figs. 10b and 11), possibly triggered by a small break in the crater rim that acted as a catchment for water.

Our focus here is on the channelized scour-like bedforms within field 1 located in the upper reaches of the delta slope (Fig. 10c). The channel rises $223 \mathrm{~m}$ over $4.3 \mathrm{~km}$ distance, giving an average slope of $3^{\circ}$. The channel and accompanying channelized bedforms start at $300 \mathrm{~m}$ wide and narrow to $115 \mathrm{~m}$ wide before disappearing. Bedforms have an average wavelength of $540 \mathrm{~m}$. This geomorphology is coined the Aeolis Mensae Channel and compared to its thoroughly investigated terrestrial analogs, i.e., Monterey East and San Mateo Channel. A relatively discontinuous series of scours in the Monterey East Channel were classified as net-erosional cyclic steps associated with the channel initiation (Fildani et al. 2006), whereas more continuous bedforms in the San Mateo Channel were found to be net-erosional to net-depositional cyclic steps related to the channel maintenance (Covault et al. 2014). In contrast to the Monterey East Channel, the Aeolis Mensae Channel appears to be more continuous, better established, and in that respect more reminiscent of the San Mateo Channel (Fig. 10c). Based on this analogy, Aeolis Mensae Channel is found to be in the late initiation or early maintenance phase by way of submarine cyclic steps emplaced by turbidity currents.

This is the first time that submarine cyclic steps have been recognized on Mars. The bedforms that are confined within the Aeolis Mensae Channel suggest powerful flow events capable of eroding the floor of the primordial northern hemispheric ocean. We postulate that the bedforms of field 1 have been likely formed by hyperpycnal flows and/or slope failures of the prograding delta front. Similar events have been observed in deltas on Earth (Hughes Clarke et al. 2014; Normandeau et al. 2016; Winsemann et al. 2018). 

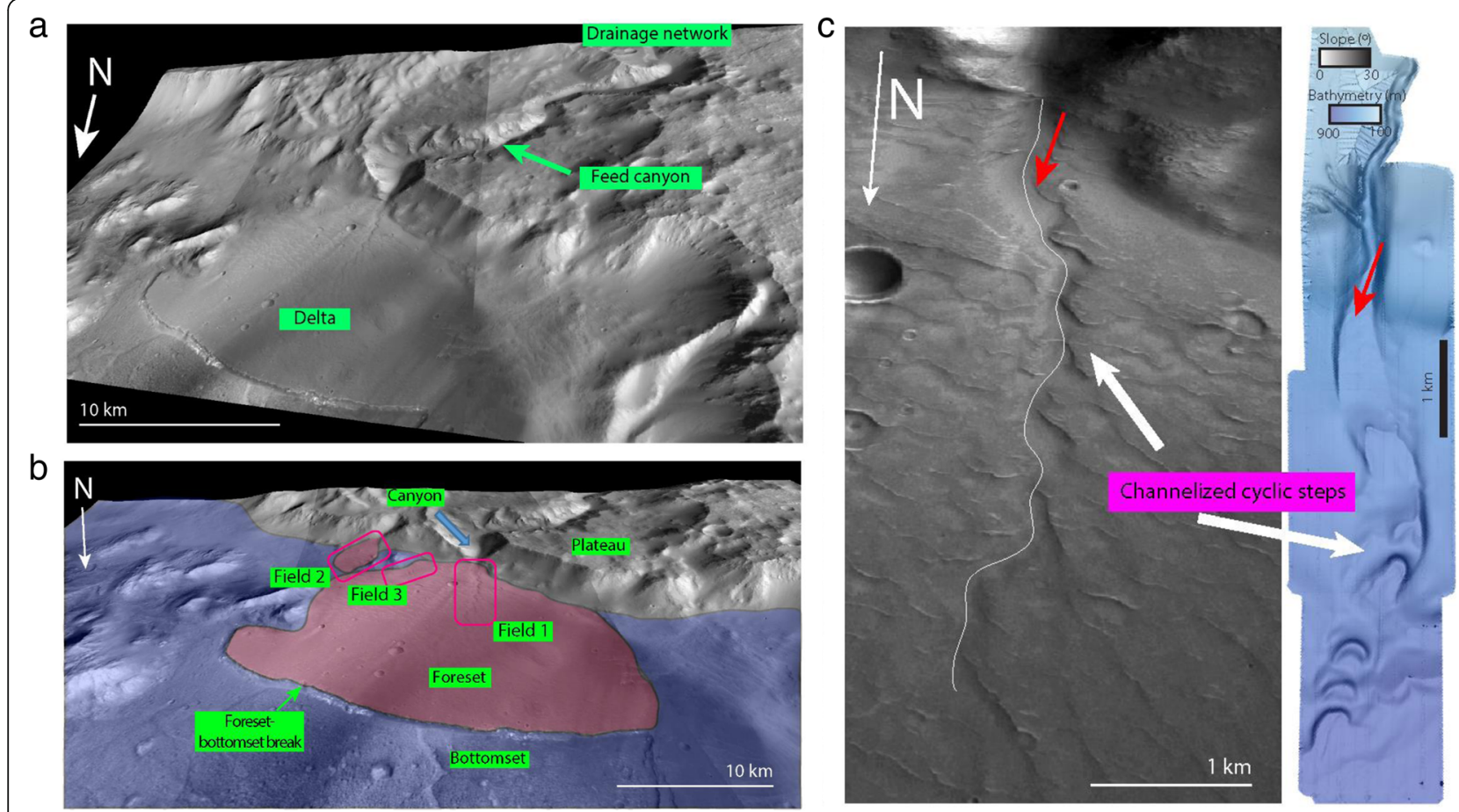

Fig. 10 Newly documented submarine cyclic steps on Mars. A compilation of HiRISE and CTX images shows a extensive valley network draining water into the feeder canyon and Aeolis Mensae Delta, $\mathbf{b}$ fields of cyclic steps on the upper foreset deposit of this delta, and $\mathbf{c}$ a close-up of field 1 of channelized cyclic steps along the Aeolis Mensae Channel (left) in comparison to San Mateo channelized cyclic steps (right). The white line (left) loosely follows the right side of the Aeolis Mensae Channel

Two additional fields of bedforms on the foreset of the Aeolis Mensae Delta (field 2 and field 3 in Fig. 11) deserve to be noted as well. The slope of field 2 is about $5^{\circ}$, and of field 3 close to $2^{\circ}$. The average wavelength of bedforms is $156 \mathrm{~m}$, and $195 \mathrm{~m}$, respectively. It is highly unlikely for the morphologic signature of net-depositional cyclic steps, such as features in field 2 and field 3, to be widely preserved on Mars due to geologic activity that has erased or modify much of the geomorphic evidence. We speculate that these fields of bedforms could be a first piece of evidence for contemporary cyclic steps generated by the sporadic presence of flowing water on Mars.

\section{Discussion}

Cyclic steps on deltas on Earth appear to be far less documented and understood than cyclic steps in overbank regions of deep-sea fans (e.g., Fildani et al. 2006; Lamb et al. 2008). Wave-like undulations on steep forest slopes (Prior and Bornhold, 1989; Gilbert and Crookshanks, 2009; Urgeles et al. 2011) are by far the most commonly reported delta bedforms. The term that is used to

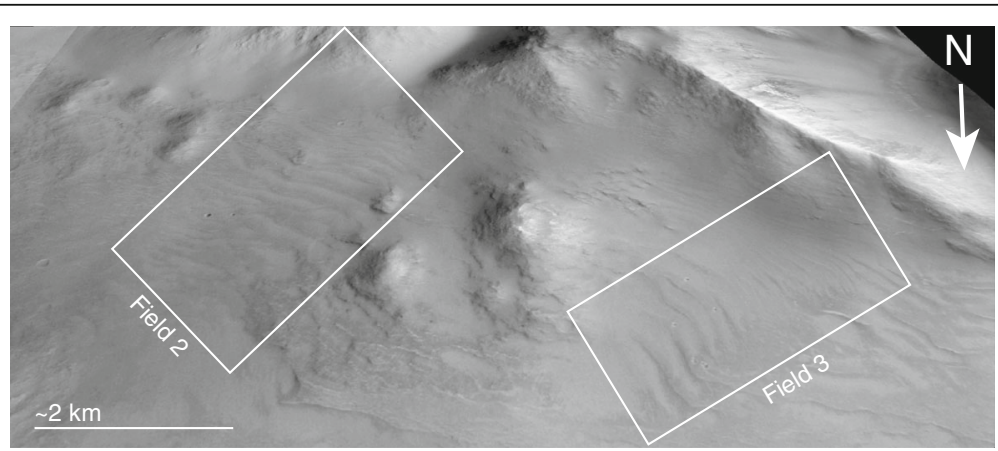

Fig. 11 A close-up of potential contemporary cyclic steps (field 2 and field 3) on the Aeolis Mensae Delta 
describe them is sediment waves or sediment undulations. The scientific community is still debating on their origin, and it will take time before many of these features get identified as net-depositional cyclic steps (Kostic 2011, 2014). Urgeles et al. (2011) noted the similarity between cyclic steps tied to channel-levee systems (Fildani et al. 2006) and sediment undulations on some Mediterranean prodeltas and introduced the idea that these undulations could be cyclic steps generated by hyperpycnal flows. A common misconception is that cyclic steps on deltas form only on the steep foreset deposits. However, cyclic steps on deltas get triggered, under the right conditions, by the foreset-bottomset transition, and can emerge upstream, downstream, or at this slope break (Kostic 2011). In addition, the upper foreset slope is commonly steeper than the downstream foreset slope due to failure and/or reworking of delta front (Kostic et al. 2002; Girardclos et al. 2012; Hughes Clarke et al. 2014). This additional slope break can work together with the foreset-bottomset transition to facilitate the flow conditions conducive to cyclic steps (e.g., Kostic 2011). Cyclic sedimentation of delta foreset can also be triggered by the periodic alternation between supercritical and subcritical flow on the delta topset just upstream of the shoreline, as illustrated in the flume experiments of Muto et al. (2012). Undulations on the delta front can be sustained as long as the inflow conditions of water and sediment support the formation of cyclic steps on the alluvial topset deposit. Other examples of cyclicity in delta foreset bedding observed in experiments should be noted as well (Kleinhans, 2005; Kim et al. 2006).

The Squamish Prodelta in British Columbia is possibly the best known natural delta laboratory, and research conducted there has significantly improved our understanding of channelized upper-flow regime bedforms on deltas emplaced by turbidity currents. The Squamish Prodelta team (Hughes Clarke et al. 2012, 2014; Hughes Clarke 2016) conducted repeat monitoring surveys (1-3-day period during 4 months) of channels on the Squamish Prodelta. They established processes of occasional, aperiodic failure of the delta front at the shelf edge and intense channel reworking by what they taught to be cyclic steps in all channels. Covault et al. (2017) applied the morphodynamic model of Kostic (2011) to small sediment waves (30$70 \mathrm{~m}$ wavelength; $2-3 \mathrm{~m}$ wave height) that dominate the floor of the Northern Channel of the Squamish Prodelta and demonstrated that these channelized features were likely transitional upper-flow regime bedforms consisting of cyclic steps and antidunes rather than cyclic steps. Recent work of Casalbore et al. (2017) reported cyclic steps in gullies on the deltaic deposit of the Mazzarrà River and outer shelf sediments along the NE Sicilian margin (southern Tyrrhenian Sea). Delta waveforms had wavelengths of $34-110 \mathrm{~m}$ and wave heights of $0.5-3 \mathrm{~m}$. They were attributed to hyperpycnal flows, but the effect of internal waves or slow deformation processes (i.e., creeps) was also noted. Casalbore et al. (2017) postulated the connection between these bedforms and the onset and growth of the Mazzarrà Delta since the Last Glacial Maximum. Some of the most illustrative examples of terrestrial cyclic steps on the foreset deposit of deltas were recently documented in lakes rather than in marine settings (i.e., Fricke et al. 2015; Normandeau et al. 2016; Winsemann et al. 2018).

Our work showcases marine cyclic steps on deltas as an additional terrestrial analog in support of the hypothetical existence of the relatively shallow northern hemispheric ocean on Mars. This is not the first time that streamlined forms shaped by turbidity currents and submarine debris flows on Earth were invoked as analogs for some Martian features (Komar 1979; Nummedal and Prior 1981). Burr (2011) argued that, due to the lower gravity on Mars, the physical sedimentology of some or all streamlined forms on Mars could to be similar to that of submarine (Komar 1979) rather than terrestrial environments on Earth. Work of Moscardelli and Wood (2011) and Burr (2014) suggests that submarine-style processes on Earth could likely provide a new analog for Martian streamlined forms in general, regardless of their proposed subaerial or submarine context.

Ojha et al. (2015) provided the strongest evidence yet that liquid water flows intermittently on present-day Mars. They used the Compact Reconnaissance Imaging Spectrometer for Mars instrument onboard the Mars Reconnaissance Orbiter (MRO) to analyze four different locations where downhill flows, known as recurring slope lineae (RSL), were present. They uncovered evidence for hydrated salts at all four locations in the seasons when recurring slope lineae are most extensive, which suggests modern-day water activity on Mars.

We speculate that the sporadic presence of flowing water in reduced-gravity environments of present-day Mars could promote the formation of contemporary subaerial cyclic steps in the vicinity of slope breaks. One such example could be two fields of cyclic steps possibly emanating from a catchment/crater upstream of the Aeolis Mensae Delta. Contemporary cyclic steps on Mars may have their terrestrial analogs in the field (e.g., Winterwerp et al. 1992) and in the laboratory (e.g., Taki \& Parker, 2005). Also, Sun and Parker (2005) explained theoretically cyclic steps in alluvium under conditions of bed aggradation or degradation, as well as in the absence of net bed level change. These newly identified subaerial cyclic steps on Mars are beyond the scope of work presented herein and deserve further investigation. 


\section{Conclusions}

Cyclic steps may have a crucial role in the onset, growth, and evolution of deltas on Earth and Mars via processes of channel avulsion, initiation, filling, and maintenance. Our research is the first modest step toward better understanding of marine cyclic steps on Mars. We were able to identify a relatively well-preserved train of cyclic steps along the Aeolis Mensae Channel thalweg on Mars, which is strikingly similar to the linear series of cyclic steps observed in channels on deltas and deep-water fans on Earth. These channelized erosional bedforms have been most likely formed by turbidity currents triggered by hyperpycnal flows and delta-front failure events. Based on the Monterey East and San Mateo terrestrial analogs, the Aeolis Mensae Channel on Mars is estimated to be in the late initiation or early maintenance phase. The analysis also unveiled potential examples of contemporary Martian cyclic steps, which are attributed to the sporadic presence of flowing water on Aeolis Mensae.

Submarine cyclic steps on Mars are a newly recognized phenomenon. The analysis presented here suggests that they can be triggered by flows that are 60\% slower than corresponding formative flows on Earth. These important upper-flow regime bedforms warrant future investigation in order to better understand the effect of reduced gravity on both ancient and contemporary streamline forms and sedimentary landforms on Mars.

\section{Abbreviations}

CTX: Context imager; DTMs: Digital terrain models; HDO: Deuterated water form; HiRISE: High Resolution Imaging Science Experiment; HRSC: High Resolution Stereo Camera; JMARS: Java Mission-planning and Analysis for Remote Sensing; MOLA: Mars Orbiter Laser Altimeter; MRO: Mars Reconnaissance Orbiter; RSL: Recurring slope lineae; TARs: Transverse aeolian ridges

\section{Acknowledgements}

SK gratefully acknowledges the conveners' travel support from the Japan Geoscience Union to attend the JpGU-AGU Joint Meeting 2017 held in Chiba, Japan. The authors thank Jacob Covault for editing the manuscript and providing helpful inputs. The paper benefited from constructive reviews by Miwa Yokokawa and Andrea Fildani.

\section{Funding}

This research is an extension of authors' collaboration dating back to 2015 and is currently not supported by any grants.

\section{Availability of data and materials}

Our findings are based on surface data for Mars collected by MOLA, CTX, HiRISE, and HRSC. These data are publicly available at the Planetary Data System and accessible easily by JMARS, provided by the University of Arizona.

\section{Authors' contributions}

SK proposed the topic, conceived the study, performed the numerical analysis, and wrote the paper. IS compiled the database, prepared the figures, and contributed to the manuscript. Both authors read and approved the final manuscript.

\section{Authors' information}

SK developed the first numerical model of submarine upper-flow regime bedforms and identified submarine cyclic steps, which paved the way for a growing recognition of the global presence and importance of these features in terrestrial deep-water environments. IS contributed to the discovery of aeolian cyclic steps on Mars Polar Layer Deposits.

\section{Competing interests}

The authors declare that they have no competing interests.

\section{Publisher's Note}

Springer Nature remains neutral with regard to jurisdictional claims in published maps and institutional affiliations.

\section{Author details}

${ }^{1}$ Computational Science Research Center, San Diego State University, San

Diego, CA, USA. ²Planetary Science Institute, Lakewood, CO, USA.

Received: 20 November 2017 Accepted: 8 October 2018

Published online: 15 November 2018

\section{References}

Allen CC, Oehler DZ, Etiope G, Van Rensbergen P, Baciu C, Feyzullayev A Martinelli G, Tanaka K, Van Rooij D (2013) Fluid expulsion in terrestrial sedimentary basins: a process providing potential analogs for giant polygons and mounds in the martian lowlands. Icarus 224:424-432. https://doi.org/10.1016/j.icarus.2012.09.018

Baker VR, Strom RG, Gulick VC, Kargel JS, Komatsu G, Kale VS (1991) Ancient oceans, ice sheets and the hydrological cycle on Mars. Nature 352(6336):589-594. https://doi.org/10.1038/352589a0

Ball FK (1956) The theory of strong katabatic winds. Aust J Phys 9:373-386

Balme M, Berman DC, Bourke MC, Zimbelman JR (2008) Transverse Aeolian ridges (TARs) on Mars. Geomorphology 101:703-720. https://doi.org/10.1016/j. geomorph.2008.03.011

Bouley S, Baratoux D, Matsuyama I, Forget F, Séjourné A, Turbet M, Costard F (2016) Late Tharsis formation and implications for early Mars. Nature 531:344-347

Bridges NT, Ayoub F, Avouac J-P, Leprince S, Lucas A, Mattson S (2012a) Earth-like sand fluxes on Mars. Nature 485:339-342

Bridges NT, Bourke MC, Geissler PE, Banks ME, Colon C, Diniega S, Golombek MP, Hansen CJ, Mattson S, McEwen AS, Mellon MT, Stantzos N, Thomson BJ (2012b) Planet-wide sand motion on Mars. Geology 40:31-34. https://doi.org/10.1130/ G32373.1

Burr DM (2011) Sedimentology in a reduced-gravity environment: submarine analogs for streamlined forms on Mars. Geology 39:703-704. https://doi.org/ 10.1130/focus072011.1

Carr MH, Head JW (2003) Oceans on Mars: an assessment of the observational evidence and possible fate. J Geophys Res 108. https://doi.org/10.1029/ 2002JE001963

Casalbore D, Ridente D, Bosman A, Chiocci FL (2017) Depositional and erosional bedforms in Late Pleistocene-Holocene pro-delta deposits of the Gulf of Patti (southern Tyrrhenian margin, Italy). Mar Geol 385:216-227

Christensen P R, Engle E, Anwar S, Dickenshied S, Noss D, Gorelick N, Weiss-Malik M (2009) JMARS - a planetary GIS, American Geophysical Union, Fall Meeting 2009, abstract \#IN22A-06

Citron R, Manga M, Hemingway D (2018) Timing of oceans on Mars from shoreline deformation. Nature 555:643-646. https://doi.org/10.1038/nature26144

Cooke M, Islam F, McGill G (2011) Basement controls on the scale of giant polygons in Utopia Planitia, Mars. J Geophys Res Planets 116. https://doi.org/10.1029/ 2011 JE003812

Costard F, Séjourné A, Kelfoun K, Clifford S, Lavigne F, Di Pietro I, Bouley S (2017) Modeling tsunami propagation and the emplacement of thumbprint terrain in an early Mars ocean. J Geophys Res Planets. https://doi.org/10.1002/ 2016JE005230

Covault JA, Kostic S, Paull CK, Ryan HF, Fildani A (2014) Submarine channel initiation, filling and maintenance from sea-floor geomorphology and morphodynamic modelling of cyclic steps. Sedimentology 61:1031-1054

Covault JA, Kostic S, Paull CK, Sylvester Z, Fildani A (2017) Cyclic Steps and Related Supercritical bedforms: Building Blocks of Submarine Fans and Canyon-Channel Systems, Western North America. Mar Geol 393: 4-20.

Di Achille G, Hynek BM (2010) Ancient ocean on Mars supported by global distribution of deltas and valleys. Nat Geosci 3:459-463. https://doi.org/10. 1038/ngeo891

DiBiase RA, Limaye AB, Scheingross JS, Fischer WW, Lamb MP (2013) Deltaic deposits at Aeolis Dorsa: sedimentary evidence for a standing body of 
water on the northern plains of Mars. J Geophys Res Planets 118:1285-1302. https://doi.org/10.1002/jgre.20100

Fairen AG, Dohm JM, Baker VR, de Pablo MA, Ruiz J, Ferris JC, Anderson RC (2003) Episodic flood inundations of the northern plains of Mars. Icarus 165(1):5367. https://doi.org/10.1016/s0019-1035(03)00144-1.

Fildani A, Hubbard SM, Covault JA, Maier KL, Romans BW, Traer M, Rowland JC (2013) Erosion at inception of deep-sea channels. Mar Pet Geol 41:48-61

Fildani A, Normark WR, Kostic S, Parker G (2006) Channel formation by flow stripping: large-scale scour features along the Monterey East Channel and their relation to sediment waves. Sedimentology 53:1265-1287

Fricke AT, Sheets BA, Nittrouer CA, Allison MA, Ogston AS (2015) An examination of Froude-supercritical flows and cyclic steps on a subaqueous lacustrine delta, Lake Chelan, Washington, USA. J Sediment Res 85:754-767

Ghatan GJ, Zimbelman JR (2006) Paucity of candidate coastal constructional landforms along proposed shorelines on Mars: implications for a northern lowlands-filling ocean. Icarus 185:171-196. https://doi.org/10.1016/j.icarus.2006.06.007

Gilbert R, Crookshanks S (2009) Sediment waves in a modern high-energy glacilacustrine environment. Sedimentol 56: 645-659

Girardclos S, Hilbe M, Corella JP, Loizeau JL, Kremer K, delSontro T, Arantegui A, Moscariell A, Alraud F, Akhtman Y, Anselmetti FS, Lemmin U (2012) Searching for the Rhone delta channel in Lake Geneva since François-Alphonse Forel. Arch Sci 65:1-16

Hamilton PB, Strom KB, Hoyal DC (2015) Hydraulic and sediment transport properties of autogenic avulsion cycles on submarine fans with supercritical distributaries. Journal of Geophysical Research: Earth Surf 120(7):1369-1389

Head JW, Hiesinger H, Ivanov MA, Kreslavsky MA, Pratt S, Thomson BJ (1999) Possible ancient oceans on Mars: evidence from Mars orbiter laser altimeter data. Science 286:2134-2137. https://doi.org/10.1126/science.286.5447.2134

Hughes Clarke JE (2016) First wide-angle view of channelized turbidity currents links migrating cyclic steps to flow characteristics. Nat Commun 7:11896. https://doi.org/10.1038/ncomms11896

Hughes Clarke JE, Brucker S, Muggah J, Church I, Cartwright D, Kuus P, Hamilton T, Pratomo D, Eisan B (2012) The Squamish ProDelta: monitoring active landslides and turbidity currents. In: Proceedings of Canadian Hydrographic Conference 2012, p 15

Hughes Clarke JE, Vidiera Marques CR, Pratomo D (2014) Imaging active masswasting and sediment flows on a Fjord Delta, Squamish, British Columbia. In: Krastel S, Behrmann JH, Völker D, Stipp M, Berndt C, Urgeles R, Chaytor J, Huhn K, Strasser M, Harbitz CB (eds) Submarine mass movements and their consequences, advances in natural and technological hazards research. Springer, Heidelberg, pp 249-260

Irwin III R P, Watters T R, Howard A D, Zimbelman J R (2004) Sedimentary resurfacing and fretted terrain development along the crustal dichotomy boundary, Aeolis Mensae, Mars. J Geophys Res Planets 109, dio: https:// doi.org/10.1029/2004JE002248

Irwin RP III, Zimbelman JR (2012) Morphometry of Great Basin pluvial shore landforms: implications for paleolake basins on Mars. J Geophys Res 117 https://doi.org/10.1029/2012je004046

Ivanov MA, Head JW (2001) Chryse Planitia Mars: topographic configuration outflow channel continuity and sequence, and tests for hypothesized ancient bodies of water using Mars Orbiter Laser Altimeter (MOLA) data. J Geophys Res 106:3275-3295. https://doi.org/10.1029/2000je001257

Kim W, Paola C, Swenson JB, Voller VR (2006) Shoreline response to autogenic processes of sediment storage and release in the fluvial system. J Geophys Res 111 (F4), https://doi.org/10.1029/2006JF000470

Kleinhans MG (2005) Autogenic cyclicity of foreset sorting in experimental Gilbert-type deltas. Sediment Geol 181:215-224

Komar PD (1979) Comparisons of the hydraulics of water flows on Martian outflow channels with flows of similar scale on Earth. Icarus 37:156-181. https://doi.org/ 10.1016/0019-1035(79)90123-4

Kostic S (2011) Modeling of submarine cyclic steps: controls on their formation, migration, and architecture. Geosphere 7:294-304. https://doi.org/10.1130/ GES00601.1

Kostic S (2014) Upper flow regime bedforms on levees and continental slopes: turbidity current flow dynamics in response to fine-grained sediment waves. Geosphere 10:1094-1103. https://doi.org/10.1130/GES01015.1

Kostic S, Parker G (2006) The response of turbidity currents to a canyon-fan transition: internal hydraulic jumps and depositional signatures. J Hydraul Res 44:631-653
Kostic S, Parker G, Marr J (2002) Role of turbidity currents in setting the foreset slope of clinoforms prograding into standing fresh water. J Sediment Res 72: 353-362. https://doi.org/10.1306/081501720353

Lamb MP, Parsons JD, Mullenbach BL, Finlayson DP, Orange DL, Nittrouer CA (2008) Evidence for superelevation, channel incision, and formation of cyclic steps by turbidity currents in Eel Canyon, California. GSA Bull 120:463-475

Maier KL, Fildani A, McHargue T, Paull CK, Graham SA, Caress DW (2012) Deepwater punctuated channel migration: high-resolution subsurface data from the Lucia Channel System, offshore California. J Sediment Res 82:1-8

Malin MC, Edgett KS (1999) Oceans or seas in the Martian northern lowlands: high resolution imaging tests of proposed coastlines. Geophys Res Lett 26:3049-3052

Malin MC et al (2007) Context camera investigation on board the Mars reconnaissance orbiter. J Geophys Res Planets 112(E5). https://doi.org/10. 1029/2006JE002808

McEwen AS, Eliason EM, Bergstrom JW, Bridges NT, Hansen CJ, Delamere WA, Grant JA, Gulick VC, Herkenhoff KE, Keszthelyi L, Kirk RL, Mellon MT, Squyres SW, Thomas N, Weitz CM (2007) Mars reconnaissance orbiter's high resolution imaging science experiment (HiRISE). J Geophys Res Planets 112 (E5), https://doi.org/10.1029/2005JE002605

Moscardelli $L$ (2014) Boulders of the Vastitas Borealis Formation: potential origin and implications for an ancient martian ocean. GSA Today 24. https://doi. org/10.1130/GSATG197A.1

Moscardelli L, Dooley T, Dunlap D, Jackson M, Wood L (2012) Deep-water polygonal fault systems as terrestrial analogs for large-scale Martian polygonal terrains. GSA Today 22:4-9. https://doi.org/10.1130/GSATG147A.1

Moscardelli L, Wood L (2011) Deep-water erosional remnants in eastern offshore Trinidad as terrestrial analogs for teardrop-shaped islands on Mars: implications for outflow channel formation. Geology 39:699-702. https://doi.org/10.1130/ G31949.1

Muto T, Yamagishi C, Sekiguchi T, Yokokawa M, Parker G (2012) The hydraulic autogenesis of distinct cyclicity in delta foreset bedding: flume experiments. J Sediment Res 82(7):545-558

Neukum G, Jaumann R (2004) HRSC: the high resolution stereo camera of Mars express. In: Mars Express: the Scientific Payload, vol 1240, pp 17-35

Normandeau A, Lajeunesse P, Poiré AG, Francus P (2016) Morphological expression of bedforms formed by supercritical sediment density flows in four fjord-lake deltas of the southeastern Canadian Shield (Eastern Canada). Sedimentology 63 : 2106-2129. https://doi.org/10.1111/sed.12298

Nummedal D, Prior DB (1981) Generation of Martian chaos and channels by debris flows. Icarus 45:77-86. https://doi.org/10.1016/0019-1035(81)90007-5

Oehler DZ, Allen CC (2012) Focusing the search for biosignatures on Mars: facies prediction with an example from Acidalia Planitia. In: Grotzinger J, Milliken R (eds) Sedimentary Geology of Mars: SEPM Special Publication, vol 102, pp 183-194

Ojha L, Wilhelm MB, Murchie SL, McEwen AS, Wray JJ, Hanley J, Massé M, Chojnacki M (2015) Spectral evidence for hydrated salts in recurring slope lineae on Mars AOP. Nat Geosci. https://doi.org/10.1038/ngeo2546

Parker TJ, Gorsline DS, Saunders RS, Pieri DC, Schneeberger DM (1993) Coastal geomorphology of the Martian northern plains. J Geophys Res 98:11061-11078. https://doi.org/10.1029/93JE00618

Parker TJ, Saunders RS, Schneeberger DM (1989) Transitional morphology in west Deuteronilus Mesae, Mars-implications for modification of the lowland upland boundary. Icarus 82:111-145. https://doi.org/10.1016/0019-1035(89)90027-4

Perron JT, Matsuyama I, Richards MA, Mitrovica JX, Manga M (2007) Evidence for an ancient martian ocean in the topography of deformed shorelines. Nature 447:840-843. https://doi.org/10.1038/nature05873

Pettré P, André JC (1991) Surface-pressure change through Loewe's phenomena and katabatic flow jumps - study of two cases in Adelie Land, Antarctica. J Atmos Sci 48:557-571

Postma G, Hoyal D, Abreu V, Cartigny M, Demko T, Fedele J, Kleverlaan K, Pederson KH (2016) Morphodynamics of supercritical turbidity currents in the channel-lobe transition zone. In: Lamarche G, Mountjoy J (eds) Submarine mass movements and their consequences. Springer, Dordrecht: 469-478.

Prior DB, Bornhold BD (1989) Submarine sedimentation on a developing Holocene fan delta. Sedimentol 36(6):1053-1076.

Rodriguez JAP, Fairén AG, Tanaka KL, Zarroca M, Linares R, Platz T, Komatsu G, Miyamoto H, Kargel JS, Yan J, Gulick V, Higuchi K, Baker VR, Glines N (2016) Tsunami waves extensively resurfaced the shorelines of an early Martian ocean. Sci Rep 6. https://doi.org/10.1038/srep25106

Silvestro S, Fenton LK, Vaz DA, Bridges NT, Ori GG (2010) Ripple migration and dune activity on Mars: evidence for dynamic wind processes. Geophys Res Lett 37. https://doi.org/10.1029/2010GL044743 
Smith DE, Zuber MT, Frey HV, Garvin JB, Head JW, Muhleman DO, Pettengill GH, Phillips RJ, Solomon SC, Zwally HJ (2001) Mars Orbiter Laser Altimeter: experiment summary after the first year of global mapping of Mars. J Geophys Res Planets 106:23-689

Smith DP, Kvitek R, lampietro PJ, Wong K (2007) Twenty-nine months of geomorphic change in upper Monterey Canyon (2002-2005). Mar Geol 236:79-94

Smith IB, Holt JW (2010) Onset and migration of spiral troughs on Mars revealed by orbital radar. Nature 465:450-453. https://doi.org/10.1038/nature09049

Smith IB, Holt JW, Spiga A, Howard AD, Parker G (2013) The spiral troughs of Mars as cyclic steps. J Geophys Res Planets. https://doi.org/10.1002/jgre.20142

Sun T, Parker G (2005) Transportational cyclic steps created by flow over an erodible bed. Part 2. Theory and numerical simulation. J Hydraul Res 43:502-514

Taki K, Parker G (2005) Transportational cyclic steps created by flow over an erodible bed. Part 1. Experiments. J Hydraul Res 43:488-501

Tubau X, Paull CK, Lastras G, Caress DW, Canals M, Lundsten E, Anderson K, Gwiazda R, Amblàs D (2015) Submarine canyons of Santa Monica Bay, Southern California: variability in morphology and sedimentary processes. Mar Geol 365:61-79

Urgeles R, Cattaneo A, Puig P, Liquete C, De Mol B, Amblàs D, Sultan N, Trincardi F (2011) A review of undulated sediment features on Mediterranean prodeltas: distinguishing sediment transport structures from sediment deformation. Mar Geophys Res 32:49-69

Villanueva GL, Mumma MJ, Novak RE, Käufl HU, Hartogh P, Encrenaz T, Tokunaga A, Khayat A, Smith MD (2015) Strong water isotopic anomalies in the martian atmosphere: probing current and ancient reservoirs. Science 348:218-221. https://doi.org/10.1126/science.aaa3630

Winsemann J, Lang J, Polom U, Loewer M, Igel J, Pollolk L, Brandes C (2018) Ice-marginal forced-regressive deltas in glacial lake basins: geomorphology, facies variability and large-scale depositional architecture. Boreas. https://doi. org/10.1111/bor.12317

Winterwerp JC, Bakker WT, Mastbergen DR, van Rossum H (1992) Hyperconcentrated sand-water mixture flows over erodible bed. J Hydraul Eng 118(11):1508-1525

Zimbelman JR (2010) Transverse aeolian ridges on Mars: first results from HiRISE images. Geomorphology 121:22-29. https://doi.org/10.1016/j.geomorph.2009. 05.012

\section{Submit your manuscript to a SpringerOpen ${ }^{\circ}$ journal and benefit from:}

- Convenient online submission

- Rigorous peer review

- Open access: articles freely available online

- High visibility within the field

- Retaining the copyright to your article

Submit your next manuscript at $\boldsymbol{\nabla}$ springeropen.com 